\title{
Data Sharing and the idea of ownership
}

\section{Jonathan Montgomery}

Faculty of Laws, University College London, United Kingdom

Professor of Health Care Law

UCL Faculty of Laws, University College London, Bentham House, Endsleigh

Gardens, London WC1H 0EG. Tel: +44 (0)20 31088359.

Correspondence to: Jonathan.Montgomery@ucl.ac.uk

Jonathan Montgomery is Professor of Health Care Law at University College London and Chair of the Health Research Authority. From 2012-2017 he was Chair of the Nuffield Council on Bioethics. From 2009-2012 he was Chair of the Human Genetics Commission.

Disclosure statement: no conflicts of interest to disclose 


\section{Data Sharing and the idea of ownership}

Ideas about ownership are sometimes used in discussions of data sharing in personalised medicine. Personal health data are thought by many to be 'theirs'. Paradoxically, personalised medicine (at least in the context of genomics) relies on the aggregation of private data into a dataset that is held as a form of knowledge commons. When the notions of private and common property that lie behind this discourse are made explicit we can use thinking about the justifications and jurisprudence of property both to clarify the persuasiveness and limits of such claims, and also how they differ from other principles that are at stake in the interplay between individual and collective goods in the delivery of personalised medicine. This shows that ownership might more plausibly lie with health professionals than patients. In a socialised medicine system, such as the NHS, such professionals are agents of the state and ownership would lie with the commons rather than any individual. Common rather than private ownership of genomic information may be more appropriate.

Keywords: health data; property; ownership; personalised medicine; commons; privacy

\section{Introduction}

The 'ownership' of personal health information is one of the metaphors that are used to organize thoughts about how the ethics of the data pooling that is essential to the delivery of personalized care should be considered. People are concerned that their health data is being wrongfully appropriated for the use of others. They see their health data as being the product of their bodies and actions, which in different ways (with antecedents in the philosophy of property) they see as therefore belonging to them. This has found its way into the law and the UK has introduced a criminal offence of 'DNA Theft' that prohibits having bodily material ('DNA manufactured by the body of a person who is alive') with the intent to analyse it without their consent or some other 
specified legal justification (which includes their diagnosis or treatment). ${ }^{1}$ Thus, the idea that my genomic information is protected as part of my private property has taken root.

However, amongst the paradoxes of personalized medicine is that the ability to advise individuals depends on the availability of a reference base of aggregated information from others. This reference base is used as a sort of communal property, in line with the vision of the Human Genome Project in protecting humanity's common thread from privatization (Sulston \& Ferry 2002). It is by comparing individuals' specific information with 'normal' expectations that the variations which appear from personalized advice can be inferred. If arrangements for the ownership of property are understood to be part of the structures by which resources are managed in a society (Ryan 1987), then we should perhaps consider what can be learnt by thinking about health information as a form of property.

\section{'My' data and data about me}

The differences between proprietary and other forms of claims can be identified in a number of ways. Property claims assert a degree of separation between owner and the thing owned. This enables owners to derive benefit through various types of dealings, including transfers. In relation to personal health data, thinking in terms of ownership facilitates the commodification of the information into a unit of exchange and invites us to think about who is entitled to control, and benefit from, the exploitation of the property. Ownership also implies a range of 'standard incidents'; entitlements to control

\footnotetext{
${ }^{1}$ Human Tissue Act 2004, s 45 and Sched. 4.
} 
the use of property that are effective against others (Honore 1960). Unlike 'personal' claims, these property rights generally hold good against all of the world and are not limited to specific individuals nor varied according to the relationship the owner has with others (although one of the incidents of ownership is the power to grant permissions to individuals as the owner chooses).

The types of wrong that are generated by property claims are different from the sort of concerns that are protected by the personal rights of patients. Although it is often claimed that there is a connection between autonomy and patients' rights, the fundamental claim that is protected by law is one of non-interference - the liberty to be left alone unless the physical intrusion has been consented to, and claims to privacy from excessive surveillance (Coggon and Miola 2011). Such personal claims are generally understood to be inalienable rights whose force is neither diminished nor exhausted by specific permissions (such as consent to a particular treatment). Our privacy interests mean that we do not need to appeal to ideas of property to establish that the use of health information requires regulation. Indeed, it works in ways that sit uneasily with property ideas. Thus, information 'about me' does not cease to be connected to my privacy when I give (or sell) it to others. If the information is owned, however, it will cease to belong to me provided that the transaction by which it is transferred is effective. Thus, it is inherent in the property paradigm that data 'about me' can cease to be 'mine' but this seems to run against the expectations that those who assert that information is 'theirs' and provides a reason to be wary of the claim.

\section{The value of property}

Political theorists have long asserted a connection between property regimes and freedom; some stressing the freedom from state interference and others the 
opportunities for participation that property owners enjoy (Ryan 1987). However, these connections arise in different ways and we shall see how consideration of some of the justifications of property points to different conclusions about the connection between control of health information and freedom. In particular, questions of justice in the distribution of property in health information can point in a number of directions. These include the nature of remedies that might be available if we deal with health data as property. Abuse of property rights can occur through damage that reduces its value to the owner(s), obstruction of peaceful enjoyment (trespass), and misappropriation (paradigmatically, theft - the dishonest appropriation of property belonging to another with the intention to deprive them of it permanently). The current owner is able to enforce their rights when such abuses occur and generally the origin of property rights is of little significance in enforcement proceedings.

\section{Am I the owner of data about me?}

Explanations of the origins of property rights are crucial, however, to assessing the attractiveness of the ownership paradigm. One strand of thought suggests that ownership is a natural right, generated by the mixing of labour with resources, that provides a powerful side constraint on the claims of states (Locke 1689, Nozick 1974). However, I cannot easily claim on this basis that I am entitled to treat my genomic information as 'belonging' to me because it was given to me rather than created by me. First, what have I done to deserve it? Although there is scope for argument and for some divergence, the principles of intellectual property law generally deny the patentability of naturally occurring things on the basis that no intellectual capital has been invested in them. Second, what have $I$ done to deserve it? Perhaps my parents created my genome, by contributing the constituent materials, but the idea that children should be treated as parental property seems grotesque in the modern world (Montgomery 1988, Archard 
1993).

I might make a different sort of claim, based on the transaction that I make with health services. By 'investing' my bodily samples to be tested I am the owner of the information that it is product. This raises two distinct problems. First, it begs the question of whether that transaction should be analysed in proprietary terms. It is true that we have traditionally thought of confidentiality in terms of the sharing of information on conditions of trust. However, the obligations of health professionals can be more easily explained by their Hippocratic obligation to do no harm and by their obligations under data protection law to take steps to protect information that they hold 'about me'. This can be seen by the fact that such obligations arise in relation to information from all sources, not just that contributed directly by the patient.

Secondly, the 'labour theory' of the origins of property may even make the claims of the health service to ownership rights over information more plausible than those of patients. This is because the information that underpins personalised medicine does not exist prior to interactions with health services. It is generated by the tests that the service carries out and the analysis that it does of their significance. The 'value' that lies in the data is derived from the raw materials (samples) but produced by the work that is done on them. The ancient Romans grappled with an analogous problem of ownership in relation to works of art. In classical Roman law, a writer's contribution was valued less than the raw materials so that the owner of the parchment on which something was written became the owner of the manuscript. With paintings, the priority was different - the artist owned the product even though the canvass belonged to someone else. Sculptures divided the schools of jurists; some thought that the sculptor 
owned the work, while others argued that the owner of the materials from which it was carved also owned the statue. The question is how we should value the contributions of the materials for analysis against those made by the professional who extracts the personal data and makes it intelligible. This contribution is significant and beyond the competence of the patient. Further, the patient loses nothing in the provision of samples or information because they retain the information and replace the samples. If anyone claim proprietary rights over the information on the labour theory of property, it would seem to be the health professionals or service for which they work.

\section{How might I own data about me?}

The assumed context of Locke's labour theory of the origins of ownership was a world of plenty in which the 'state of nature' could be improved by cultivation without loss to others. Thus, private ownership was acceptable provided that 'as much and as good' was left for others, who could similarly make wasteland productive through its appropriation. In a world of scarcity, property becomes a 'zero sum' game in which attributing private ownership of something to one individual leads to their gain at the expense of someone else. In such circumstances, the attractiveness of the labour theory is less obvious. It might entitle those who create property to some form of reward. However, it does not explain why we should accept the corollary that private property creates, that others will be excluded from it

Further, we are already more intimately connected with the material over which property than is assumed in the Lockean conception of a vast uncultivated state of natural resource. Almost all of our genomic health data is in fact shared by others - the variations that make us individuals are tiny compared to what we hold in common. To allow the assertion of an exclusionary private ownership by one individual over all 
aspects of their genome would be to deprive others of the possibility of exploiting their own in a similar way. Such an appropriation would require a robust justification.

However, we could still seek to defend the usefulness of an ownership paradigm by considering the differences between private, public and common property (Waldron 1988). Things are considered public property when they can be used by everyone without exclusion and exhaustion. Thus, air is a public property because we can all breathe it and the availability to others of air to breathe is not diminished by the fact that I am breathing it too. The human genome can be seen as an example of such a public good. Understanding it as public property explains why it is legitimate for states to take steps to preserve it and to protect its value. Understanding it as public property enables its value to be secured for all and not appropriated by a private owner who then permits access to others only at a price.

However, it is perhaps more convincing to consider individual genetic information as a form of common property belonging simultaneously to a group of people but with outsiders excluded. Parker and Lucassen (2004) examined this in relation to familial genetic information, which is intelligible as part of a family resource, and described it as a 'joint account' account model in which the resources are pooled for common use by family members. Their approach has been influential in guidelines and practice (British Society for Genetic Medicine/Joint Committee on Medical Genetics (2011)) not least because of their leading positions in co-ordinating practitioners' explorations of 'genethics' and in Genomics England. The common property model explains why the use of the information by the co-owners is justified and also the importance of enabling its value to be maximized. It also explains why the protection of the data against abuse by others is appropriate. However, it does not demonstrate that this is the only, or best, way to capture our stake in the genetic information that we 
share with those to whom we are closely related. Nor does it in principle exclude the possibility of public ownership of such health information.

\section{Conclusion}

Empirical work by Dheensa et al (2016) has shown that the joint account model is consistent with the attitudes of at least some families. However, language used to explain the way it was expected that data should be used was as much about family privacy as about ownership. Property ideas were expressed as limiting rather than enabling:

I felt as if that blood should have been everybody's, but I know it's her blood and it's her result, but I felt like that result should then have gone into a bank for any people that may be affected by it. But I don't know whether that would ever be something that you could, because obviously it's not my blood, it's her blood. I think there needs to be a way-because there's too many people out there in my situation - where if they are doing the test that it becomes public for the family.

However, common ownership amongst families cannot secure the appropriate use of health information for the benefit of humankind. Its attraction lies primarily in an enriched sense of privacy that can accommodate both our needs for protection from those close to us but also our connections with them. These are not proprietary but personal interests.

In short, treating health information as the private property of patients is hard to justify on the traditional 'labour theory' of ownership. That approach would instead suggest that health information derived from patients should be owned by health professionals (or more plausibly the health systems for whom they work). However, giving either patients or individual professionals the right to extract ransom payments from those seeking to use genomic science to provide personalised medicine enables them to appropriate to themselves material that is biologically common to others. Public 
ownership of genomic information is a more convincing model. It recognizes obligations of stewardship to preserve and make productive use of the property without limiting the ability to secure a just distribution of the benefits. 
Archard, D (1993) 'Do parents own their children?' 1(3) International Journal of Children's Rights 293-301.

British Society for Genetic Medicine/Joint Committee on Medical Genetics (2011) Consent and confidentiality in genetic practice. (London, Royal College of Physicians and Royal College of Pathologists).

Coggon, J and Miola, J, (2011) Autonomy, Liberty and Medical Decision-Making. 70(3) Cambridge Law Journal 523.

Dheensa, S, Fenwick, A, Lucassen AM (2016) “"Is this knowledge mine and nobody else's? I don't feel that." Patient views about consent, confidentiality and information-sharing in genetic medicine' Journal of Medical Ethics 42:174-79.

Honore, A (1960) ‘Ownership’ In: Guest, A G (Ed) Oxford Essays in Jurisprudence (Oxford, Oxford University Press) 104-47.

Locke, J (1689) Two Treatises of Government (Cambridge: CUP ed P Laslett 1988).

Montgomery, J (1988) 'Children as Property?' 51 Modern Law Review 323-42.

Nozick, R (1974) Anarchy, State and Utopia (New York: Basic Books).

Parker M, Lucassen AM. Genetic information: a joint account? BMJ 2004;329:165-7.

Ryan, A (1987) Property (Buckingham: Open University Press).

Sulston, J, Ferry, G, (2002) The Common Thread: A story of science, politics, ethics and the human genome. (London, Bantam Press).

Waldron, J (1988) The Right to Private Property (Oxford: OUP) 